\section{Animal rights activists raise a storm in California}

\section{Berkeley}

OVER the loud protests of animal rights groups, the California legislature has approved funding for a new $\$ 12.5$ million animal facility on the campus of the University of California (UC) at Berkeley. Construction is scheduled to begin in July.

The Northwest Animal Facility, in the planning stage for several years, has come under relentless attack by animal rights organizations, which see it as a sign of the university's continued commitment to animal research. The groups have drawn considerable public attention with campus demonstrations and press conferences. Because of these lobbying efforts, the state legislature's financing for the facility may come with strings attached: a legislative committee will decide by 15 June whether to ask UC to carry out a study of alternatives to animal research, or to place two animal rights activists on the Berkeley Animal Care and Use Committee (ACUC), the group responsible for enforcing the National Institutes of Health guidelines for animal care.

The university says it will try to honour the legislature's requests although they are not legally binding. It may balk, however, at placing animal rights activists on the committee, says ACUC chairman Rick Van Sluyters, because the pool of organizations from which the members would be chosen are all strongly opposed to animal research. As a gesture of good will, UC appointed an animal activist to the committee in 1985, but her presence was disruptive, says Van Sluyters, as she operated outside ACUC guidelines, trying to change rules the committee is authorized only to enforce. She resigned last November, criticizing the committee as a "rubber stamp" for researchers' interests.

Berkeley's five-year struggle with animal rights groups is a "case study in what can go wrong", says campus veterinarian Roy Henrickson, who directs the Office for Laboratory Animal Care.

When Henrickson took the job in 1984 , he was faced with ageing, decentralized animal quarters that were difficult to regulate and maintain. The campus had lost its accreditation by the American Association for the Accreditation of Laboratory Animal Care (AAALAC), and a new, centralized animal facility seemed the logical way to regain it. That goal has been continually opposed by animal rights groups. Henrickson says he made the early mistake of dismissing the activists as "buffoons", not realizing that they would be accepted by the community as more credible than university officials.

Henrickson admits that animal care at Berkeley was flawed in the early 1980s, research universities.

variable in quality and an easy target for criticism. But the activists are doing their best to thwart the university's efforts to remedy the problems, he says. Henrickson believes Berkeley's problems are a harbinger of times to come for other

Just before legislative budget hearings on the new facility, the New-York-based

\title{
New cohesion for UK computer research
}

\section{London}

THE direction of Britain's governmentfinanced research and training in information technology will in future be largely determined by a new panel of academics and industrialists in an effort to produce a coherent national strategy. The Department of Trade and Industry (DTI) and the Science and Engineering Research Council (SERC) has announced that a new 'advisory structure' is to be established, drawn from the academic and industrial sectors "in roughly equal numbers" and headed by a single advisory body reporting to both SERC and DTI on research strategy, resource allocation and individual applications for support (although both SERC and DTI wil retain their normal procedures for awarding grants).

It is significant that a research council (which gets the bulk of its cash from the Department of Education and Science)
Fund For Animals launched a media campaign against Van Sluyters, a professor of optometry. His research on the development of the mammalian visual system was named "the most cruel, worthless animal research of the year," and leaflets were distributed on campus showing kittens with their eyes stitched shut. Van Sluyters countered by sending legislators a packet of letters of support from colleagues around the country, including Nobel laureates David Hubel and Torsten Wiesel, testifying to the quality of his work.

has agreed effectively to pool its entire budget for a substantial area of research with that from another government department. SERC's expenditure on information technology this year is expected to be $£ 28$ million on research and $£ 14$ million on education and training. DTI's expenditure on research will be $£ 50$ million.

The full structure of the advisory committees and the details of management arrangements have not yet been finalized, although it is envisaged that under the main committee, three principal subcommittees will concern themselves with devices, systems, architecture and systems engineering.

The hope is that the existence of a mechanism allowing a strategic overview will make it simpler for other government departments, such as the Ministry of Defence, to enter collaborative programmes. Simon Hadlington

\section{Hughes Institute to benefit minorities \\ Washington}

ThE Howard Hughes Medical Institute last week awarded grants totalling over $\$ 30$ million to undergraduate programmes in biology and related sciences at 44 colleges in the United States. These grants, awarded chiefly to liberal arts and historically black colleges, make up the largest amount ever given by a private organization for undergraduate education in the biological sciences.

The minimum grant is $\$ 400,000$. Four colleges receive over $\$ 1$ million, topped by Xavier University, a leading "historically black institution educating students in the sciences". The top four (ranked by amount received): Xavier University of Louisiana ( $\$ 1.8$ million), Haverford College, Pennsylvania ( $\$ 1.2$ million), Wesleyan University, Connecticut $(\$ 1.2$ million) and College of Wooster, Ohio (\$1.0 million)

The institute's president, Purnell W. Choppin, stressed the importance of ensuring "an adequate supply" of welltrained medical researchers in the future, and of increasing the number of people from minority groups entering biomedical research careers. The institute's selection process also stressed the importance of interdisciplinary programmes.

The new undergraduate grants complement the Hughes Institute's plan to finance 300 doctoral fellowships per year in the biomedical sciences. Both these educational programmes are part of a campaign by the private research organization to fund science education in addition to basic research programmes.

Unveiled last October, this campaign will provide $\$ 500$ million to support science-related activities - primarily in education - over the next ten years.

Ironically, the news of the minoritytargeted Hughes grants came just as a blue-ribbon panel chaired by former Presidents Jimmy Carter and Gerald Ford released a report announcing that the United States has "lost ground" in its efforts to achieve participation from minority groups in government, education and other institutions. Despite a growing pool of minority high-school graduates, according to the panel, a smaller percentage attend college today in the United States than in 1975.
Seth Shulman 